\title{
The Making of Muslim Millennial Moderate Identities through Sufistic Multicultural Da'wah
}

\author{
Lukman Al Farisi ${ }^{1}$, Abdul Muhid ${ }^{2}$, Arya Abdul Fattah ${ }^{3}$ \\ 123 Universitas Islam Negeri Sunan Ampel Surabaya, Al Azhar University \\ ๑ Contact email: lukmanalfarisi56@gmail.com
}

Received: June 22, 2020 | Revised: Sept 28, 2020 | Approved: Feb 12, 2021

\begin{abstract}
Multicultural - Sufistic Da'wah is interesting to discuss, considering that multicultural and Sufistic preaching has long been a feature of Islamic preaching in Indonesia. However, in its development, the pattern of people's lives has undergone significant changes. One of them is the rapid growth of information and communication technology that has created a spiritually fragile millennial generation. The role of multicultural and Sufistic preaching is considered very important in guarding millennial Moslem's life. This article concludes that Sufistic da'wah's need is significant for the millennial generation to guide spirituality and modern religious identity through a qualitative approach with this type of literature study research. At the same time, growing diversity requires a complementary approach, namely the preaching of multiculturalism to guard the plurality of diversity in the millennial era. The two of them have a significant relationship to reach the Ulul Albab generation.
\end{abstract}

Keywords: Da'wa, Sufism, Multiculturalism, Millennials

Abstrak: Dakwah multikultural-sufistik menjadi menarik untuk dibahas mengingat dakwah multikultural dan sufistik telah sejak lama menjadi corak dakwah Islam di Indonesia. Namun di dalam perkembangannya, pola kehidupan masyarakat telah mengalami perubahan yang signifikan. Salah satunya akibat pertumbuhan teknologi informasi dan komunikasi yang sangat pesat sehingga menimbulkan generasi milenial yang rapuh spiritual. Sehingga peran dakwah multikultural dan sufistik dinilai sangat penting di dalam mengawal kehidupan milenial muslim. Melalui pendekatan kualitatif dengan jenis penelitian studi literatur, artikel ini menyimpulkan bahwa kebutuhan dakwah sufistik sangat penting untuk generasi milenial sebagai pengarah spiritualitas dan identitas keagamaan yang moderen. Di saat yang sama, keberagaman yang terus tumbuh memerlukan pendekatan komplementer yaitu dakwah multikulturalisme untuk mengawal pluralitas keberagamaan di era milenial. Keduanya memiliki hubungan penting untuk mencapai generasi Ulul Albab.

Kata Kunci: Dakwah, Sufistik, Multikultalisme, Milenial

\section{Introduction}

Da'wah is part of the obligations of Muslims. There is an affirmation that what is right must be done in preaching, and what is terrible must be avoided. According to Ali Mahfudz, da'wah is to encourage people to do good and follow religious instructions, call 
them to goodness and prevent them from munkar to get happiness in the world and the hereafter (Mahfudz, 1970). Meanwhile, today, da'wah has begun to develop following the circumstances, situations, the development of the media of preaching, the preacher's character ( $\left.d a^{\prime} i\right)$, the audience (mad'u), messages and methods used. Therefore definitively da'wah can be formulated in various contexts (Muhiddin, 2002).

It cannot be separated from the notion of da'wah, which has experienced development and differences in meaning according to science's development rate (Syafriani, 2017). This reason is also supported by the number of verses that explain the term da'wah in different contexts (Munir \& Wahyu Ilahi, 2006). In practice, da'wah can be differentiated based on the perpetrator's style, the method, and the material tendency.

One of the long-standing preachings is multicultural preaching. In following the multicultural approach, contemporary da'wah is no longer oriented to quantity, but more to quality, namely, justice, equality, and welfare for universal humanity (Zaprulkhan, 2017). Currently, preaching with this model is starting to be carried out by preachers concerned about awareness. Because they are multicultural people who are aware of the existence of minorities and see the position of the majority so far as the goodwill of the minority (Azra, 2015). This kind of preaching model needs to be given full attention and it can be an excellent opportunity for those who want to serve religion, especially in the field of da'wah.

On the other hand, the da'wah concept, which has also begun to be developed a lot, is sufistic da'wah, namely da'wah, which is considered to have existed simultaneously as Islam's coming to Indonesia. AH. Johns, one of the figures who put forward the Sufi theory, has proposed that wandering Sufis, especially those who broadcast Islam, have succeeded in Islamizing the archipelago's large population since the 13th century (Haryanto, 2014). So that Sufistic preaching is not a new kind of preaching. One of the factors is the Sufists' ability to present Islam in an attractive form, primarily through emphasis and adaptation to Islam or continuity, rather than changes in local religious beliefs and practices (Azra, 1998). Meanwhile, in Indonesia's Islamic style, tasawwuf or Sufistic has become an inseparable part of the Muslim community's religious pattern in Indonesia, especially for Sunni adherents (Setyawan, 2020).

Meanwhile, in a broader context, society's development has changed since the advent of technology, which has led to a new type of society known as millennials. It is 2 
inseparable from the entry of the 4.0 industrial revolution which requires humans to enter into technological development (Achmad, 2019). One form of millennial behavior relies on the internet, which is then used to find various information, including gathering information before deciding to buy a product or use a service (Hidayatullah, 2018). Most interestingly, the millennial has multi-talented, multi-lingual, and more expressive and explorative (Wahana, 2015). This condition and character must be understood at this time, how changes in the world are visible in technological matters and have influenced the social changes of humans who live today. This article will look deeper at the role of multicultural-Sufistic preaching in the current millennial era.

Seeing the reality of the da'wah that is developing is quite varied. The conditions and conditions of the world that have led to new categories of people living today, then da'wah must also be done by adjusting existing conditions. Many studies or articles have discussed multicultural da'wah, Sufistic, and preaching to the millennial. For example, as presented by Sokhi Huda in Colloquium, Joint Conferences, Joint Research, and Articles Publishing at Sunan Ampel State Islamic University (UIN) Surabaya with the Faculty of Islamic Studies at Universiti Sultan Zainal Abidin (UniSZA) Terengganu, Malaysia, The Sufistic Da'wah of the Hizmet M. Fethullah Gulen Movement (Huda, 2018).

Meanwhile, it is related to multicultural da'wah, written by Nawawi, about "Da'wah in a Multicultural Society" (Nawawi, 2012). Then also written by Zainol Huda about "Multicultural Islamic Da'wah: Methods of Da'wah of the Prophet SAW to people of other religions" (Huda, 2016.). The above research only describes multicultural and sufistic preaching independently without any relationship or linkage between both. The research will explore the relationship between multicultural-Sufistic da'wah which is related to one another.

\section{Method}

The research method is significant as a way to achieve the intended research results. Meanwhile, what is meant by research methods is a general strategy that will be used or adopted in data collection and data analysis, which will later be used to answer the problems at hand (Mundir, 2005). The research method becomes essential as an inseparable unit in research. Without a method, researcher cannot do research. In 
scientific terms, research means looking back (Bachtiar, 1997). So that the research method means a unit that will be used in the research process.

The type of research in this article is literature study. Literature study means carrying out a series of activities relating to collecting library data, reading and taking notes and processing research materials (Zed, 2003). According to M. Nazir, a literature study is a data collection technique by conducting some studies of books, literature, notes and reports that have a relationship with the problem (Nazir, 2014). This means that literature studies or librarian studies mean examining various literature related to the article's theme or research.

The approach in this article uses descriptive qualitative. Burhan Bungin explained that qualitative research has a higher level of criticism in all research processes (Bungin, 2007). The researcher chose qualitative research to provide an indepth review of the theme of this article. The use of relevant literature is every day in qualitative research after data collection and analysis (Azmar, 2001). According to the article's topic, the relevance of the research literature data sources is significant to note in this article.

\section{Findings and Discussion}

Millennial is often seen as a generation that is highly dependent on information and communication technology. Millennial is often referred to as "Y-Generation" (Putra, 2016). While on the other hand, the millennial is also considered the largest generation of very fond digital or digital native multitaskers (Sulistyawati \& Santosa, 2019). This characteristic indicates that the millennial has indeed grown when information and communication technology is developing rapidly.

The closeness to information and communication technology cannot be separated from the birth of various new social media or platforms, often referred to as social media such as Facebook, Twitter, Instagram, Youtube, WhatsApp and other entertainment applications, such as Tiktok. Even millennials, they are accessing an application such as LINE meets their social and psychological needs (Naldo \& Satria, 2018). It is not surprising that their generation spends most of its time accessing social media.

Its proximity to social media is often used as a medium for discussion and debate. It is also considered a common symptom among millennial as a generation that 
can never be separated from the use of the internet and social media in particular (Sabani, 2018). Coachman debates can occur because of the swiftness of various incoming information, and not all information is correct, aka hoaxes. Hoax information has penetrated various social media kinds, such as WhatsApp, Instagram, and Facebook (Walidah, 2017). The traits inherent in such millennials are dynamics in social life. Millennial as active social media users need to understand that freedom is formed in social media and the internet is not freedom that has no limits (Fahrimal, 2018).

The millennial era is also marked by institutional culture changes, for example, in an educational institution. The values of character education are fundamental to be instilled in the millennial as the nation's successor so that schools have a strategic role (Purwantiningsih, et al, 2019). The pattern of education and the application of character education must be adapted to the millennial era. The goal is to prepare the current millennial for the effects of globalization that are currently taking place (Lalo, 2018). The current globalization is the main issue that always sticks with the millennial. The current development of globalization has now given birth to a generation of gadgets, a term that is often used to mark the millennial's emergence (Anwar \& Salim, 2018).

On the other hand, the flow of globalization and information that continues to hit indefinitely is considered to have a negative impact because it can provide opportunities for foreign cultures' entry, also considered incompatible with Indonesian character culture (Rahmatullah \& Said, 2019). Therefore, the millennial needs character education in building morality (Wahono, 2018). The character is visible in the millennial's social behavior. For example, in showing or expressing their talents, they are more likely to channel it through social media or cyberspace (Rohmiyati, 2018). For millennial adolescents, such expressions are a cultured, prosocial form such prosocial behavior will affect their socializing interests and interacting with their social environment (Akhsania, 2018). Millennials who spend more time on social media are also considered to have helped shape them to become asocial.

As a result of such behavior, they are millennial adolescents who are also considered less able to develop their ability to interact on various products from technological advances (Zhafira, 2018). Their interactions are mostly carried out through technology even technology affairs then become the leading business compared to other matters (Haq, 2020). The more visible behavior in religion is behavior in 
religion. The millennial Islamic hijrah movement phenomenon that is currently happening cannot be separated from social media's influence, which is intensely accessed by the millennial generation (Fajriani \& Sugandi, 2019). This means that the millennial community's social world has been heavily influenced by the information technology they consume in their daily lives.

\section{Multiculturalism in Da'wah}

Indonesia as a country that has various ethnicities, religions, races, and languages is known as a pluralistic and multicultural country. The term multiculturalism includes an understanding, curiosity, appreciation, respect, and an assessment of others' culture (Lubis, 2006). Multiculturalism is motivated by a need to recognize an existing cultural pluralism and has become a reality in every day life in various nations, including Indonesia (Irhandayaningsih, 2012). Even in Indonesia, multiculturalism grows and develops from Indonesian nationalism (Tilaarm, 2014). The awareness of multiculturalism in Indonesia is essential, including in religious activities such as da'wah.

Da'wah requires a unique strategy in dealing with problems related to multiculturalism. Da'wah multiculturalism is a da'wah thought that focuses on the delivery of Islamic messages, in the context of a plural society, through dialogue to find common ground or agreement on something that might be agreed upon, and various places for things that cannot be agreed (Ismail \& Hotman, 2011). It means that multicultural preaching is more accommodating to the reality of existing differences. Da'wah cannot ensure a variety of religions (Marfu'ah, 2017). The essence of multicultural da'wah itself is preaching within the existing diversity and has become a reality in human life.

In the last five years, Indonesia has experienced a crisis of awareness of differences which is a necessity. Even though each community culture group certainly has a value, a paradigm of thought, and a philosophy of life that is different from one another (Rehayati, 2012). The preachers need to be aware of this such as Abdurrahman Wahid (Gusdur), who uses two approaches in his multicultural preaching, including structural and cultural approaches in preaching. (Wahyunanto, et al., 2021). One of the teachings is compassion. (Pardianto, 2015). The concept of compassion is essential in 
multiculturalism, and has been practiced by many prophets. The love in the Prophet Muhammad's hands is like a magic key with which he opens a heart that is so hard and rusty that no one thinks that it can open it (Bisri, 2014). Multicultural da'wah must be built on a foundation of compassion. The human being is given the freedom to act, sort and choose (Shihab, 2002). Multiculturalism in da'wah must be seen as an important concept of justice and minority rights (Kymlicka, 2000).

On the other hand, multicultural education in forming religious perceptions is undoubtedly very much determined by a rational argument to strengthen the impetus for the inclusion of a pluralistic attitude in Indonesian Muslims' religiosity (Rosyada, 2014). A pluralist attitude needs to be encouraged in response to world social realities, including in Indonesia. Indonesian society's statement is a pluralistic society must be seen as a national asset and not a risk or burden (Afandi \& Munif, 2018). Da'wah also sees that multiculturalism is an asset that must be appropriately managed as a da'wah field that can create harmony in social life, culture, state, religion, and nation.

Nevertheless, the obligation to preach to do amar ma'ruf nahi munkar for every believer can undoubtedly be adjusted according to their abilities, whether by taking up arms or other means (Salmadanis, 2000). However, the preachers in Indonesia had previously taught how da'wah should be carried out, either using various methods, techniques, strategies or whatever made the da'wah successful. Meanwhile, the most important thing is to understand that preventing evil is mandatory as has also been explained by the Qur'an (Azis, 2009). The awareness that da'wah is an obligation for the Islamic people is the most critical basis, and will encourage Muslims to preach. This is important because each of the seeds of evil has its power to move, when it was a child, evil was like embers that were difficult to kill (Natsir, 1989).

\section{Sufism in Da'wah}

One of the da'wah styles that are considered humanist in addition to multicultural preaching is Sufistic preaching. However, this preaching model requires the competence of preachers who understand the principles of tawassuf. The reason is that the implementation of da'wah can be effective and efficient if sufistic preaching can achieve preaching, and in achieving it, a reasonable sacrifice is issued (Nawawi, 2009). In this position, preachers' role for da'wah activities is essential because without 
preaching Islam's teachings are only ideologies that do not materialize in people's lives (Aminudin, 2016). The sufistic da'wah also requires a capable preacher, understands the principles in tasawwuf, and understands the different ethics.

The role of tasawwuf in da'wah is significant. Tasawwuf has its style in it, which is seen as a pacifist message. This view follows the preaching that invites people to do good, introduce divinity, guide the straight path, teach good deeds and nahi mungkar, benefit the world, and the hereafter (Jannah, 2019). One approach that can be taken is through sufistic preaching. In general, Sufism is meant by preaching that is similar to what is done by Sufis (Elmansyah, 2016). Sufis are known as da'i who always teach compassion, are gentle to others, always arrange their hearts, clean the day from despicable qualities to always say polite. In Indonesia, tasawwuf is widely introduced by figures who spread the religion of Islam. Tasawwuf has developed along with the development of Islam itself.

In Madura, for example, tasawwuf is a choice for the Madurese Muslim community in achieving a spiritual degree. One of the famous Islamic figures in Madura was Kiai Kholil Bangkalan, a figure who is considered to be one of the figures who participated in developing tasawwuf education in Madura. Kiai Kholil Bangkalan made Sufism a way of life through spiritual wandering to the holy land (Takdir, 2016). In its history, Kiai Kholil Bangkalan was thought to have learned tasawwuf from Shaikh Ahmad Khatib Sambas who was also the founder of the Qodariyah wa Naqsabandiyah order around 1859 (Zulmi, 2013). Historical records show that tasawwuf has been developing for a long time. Tasawwuf in Indonesia has indeed spread through the tarekat, which has become a place for the growth of Sufistic preaching itself. Shaikh Ahmad Khatib Sambas himself is the founder and follower of the Qodariyah wa Naqsabandiyah order (Aqib, 1999). It means that tasawwuf can spread in Indonesia through tarekat that religious leaders have taught in its day.

One of the most widely recognized tarekat is the Naqsabandiyah, Qodariyah and Tijaniyah (Bruinessen, 2012). These types of tarekat have developed in Indonesia in their role in spreading the teachings of tasawwuf. This is inseparable from preaching by the Sufis, who have put forward teachings with the principle of gentleness. The harmony approach with the local community is beneficial in showing that Islam brought by the guardians has genuinely carried the love of peace without violence (Siroj, 2014). Tasawwuf has taught how humans can hold back their desires to reach the degree to 8 
Allah SWT. In a broader aspect, examples of Islamic da'wah in Madura have shown how the tasawwuf approach can touch people's lives. Even Madurese values (madurology) get thicker when in contact with Islam as a rahmatan lil 'alamin religion, and can be seen in parts or variants of its rituals, meaning Madurese Muslims, especially Sumenep regarding practice or ritual (Mulyadi, 2018). Tasawwuf can deliver into various aspects of life. Sufism itself is expected to be able to bring people to a new life system with full awareness, in this case it is to rediscover the meaning and value of a moral, ethical life which is full of spirituality wrapped in Sufism (Muhaya, 2001).

Tasawwuf as one of the preaching that can enter into local culture like the one in Madura is undoubtedly exciting. On the other hand, the relationship between tarekat and Sufism cannot be separated, such as sweet and sugar, salty and salt, because initially the tarekat was part of the teachings of Sufism (Cholil, 2018). Tasawwuf is considered a way to get closer to Allah SWT as if it were a medium to let go of longing. Sufism serves as a vehicle to fulfill that longing (Djamaluddin, 2008). If we look at that role, then sufic preaching is needed to bring human spirits to their god.

In religious education institutions such as pesantren, tasawwuf is a mandatory teaching. The students are trained to be able to apply their Sufi values to everyday life. As developed by the Al-Hikam Bangkalan Islamic Boarding School concerning spiritual education based on Sufism, several formulas such as repentance nasuha, zuhud, wara ', and tawakal (Rahmatullah, 2019). Although not through the tarekat, tasawwuf education in certain aspects has gone hand in hand with the concept of education in religious institutions. Sufism or Sufistic education is not only for those who have grown up, but can also be taught from an early age. Sufistic-based spiritual education is intended to equip children to commit to carrying out Islamic teachings in depth (Aziz, 2017). Meanwhile, in the world view of Islamic monotheism, the manifestation of all existing intelligence will not be meaningful, precisely when it is not based on spirituality (Syuhud, 2014). Here then the role of Sufism in human life is essential, as a form of real intelligence and will bring calm to the human soul who has lived it. The spiritual intelligence is very full of religion because Muslim spirituality is Allah SWT (Hamzah, 2018). This real intelligence is what humans seek to achieve a high degree in the world's life and the hereafter. Therefore, in tasawwuf, a person will be taught to enter the inherent area, namely, a union to Allah SWT (Rahmatullah, 2019). 


\section{Multicultural-Sufistic Da'wah in the Millenial Era}

Da'wah must follow the times. One of them is by targeting the millennial as object which preachers must consider. One of the essential points, why millennials should target millennials, is that millennials are more widely known as the generation who are happy to spend time in their lives on online media networks (Habibi, 2018). This primary character becomes essential as a target and they are not trapped with something that can undermine their spirituality due to the influence of social media and the like. The millennial is the upper middle-class generation. Meanwhile, the da'wah approach to the middle class in Indonesia has been played more by particular study institutions such as the Paramadina Waqf Foundation (Aripudin, 2016).

In multiculturalism, the current millennial's association has surpassed many ethnicities, races, religions, cultures, and the like. It can be seen how educational institutions are starting to open up opportunities to study across regions, even across continents. Multiculturalism itself responds to a reality in which society is always plural and not monolithic (Ibrahim, 2008). In this context, there are cultural exchanges that the millennial generation will undoubtedly experience. The possibility of a seed dispute in a multicultural society such as in Indonesia will be very prone to occur if addressing a difference as a separator and causing us to be ours (Lestari, 2015). Therefore, multicultural preaching in the millennial era must be adequately developed.

Targeting millennials in multicultural preaching is very important to do. The age will continue to develop together with the name of the era's term appears. On the other hand, applying multiculturalism values can be done through history learning materials (Lestariningsih, 2018). Da'wah should adhere to how da'wah is in the millennial era, but how can da'wah be carried out to millennials, by inserting histories with multiculturalism values and requires special attention. Attention is an essential and absolute factor for persuasion efforts (Suhandang, 2014). Furthermore, the millennial is the target of da'wah, but it can become the perpetrators of da'wah itself. For millennial da'i, da'wah activities are not the only primary activity, on the other hand, millennial da'i further has other activities as the primary profession, such as teachers to employees in government agencies (Nashrillah, 2018). Overall, the da'wah characters who spend more time surfing through their social world must be well understood. Even sometimes in cyberspace, it often ends in a coachman debate (Akmaliah, 2020). These debates will 
usually take place fiercely without ever caring about the substance in them without relying on valid data references. It takes up much productive time, and often ends in a fight (Sabani, 2018).

In that position, the role of Sufistic da'wah is needed. If we look at the existing history, Muslim Sufi groups are even prevalent in China with loyal followers (Aripudin \& Abdullah, 2014). The character of loyalty to Sufi followers in China seems to be an opportunity, if the Sufi value is also used as a way of da'wah or even the da'wah's message itself. Moreover, in the current era of modernization, it has harmed the birth of moral decadence, anarchist actions and actions that are considered deviant so that humans experience spiritual emptiness. This spiritual emptiness further strengthens the importance of sufistic preaching among millennials, so that their spirituality can be filled. (Mutmainah, 2018).

A sufistic approach to da'wah is needed in the millennial era like today. The building spiritual-religious awareness of the people which in the end will also build selfawareness to be closer to Allah (Tajuddin, 2014). Forcing to adapt to the millennial era is certainly not an easy thing. However, it needs to be realized that the sparkling world of technology must be balanced with high spirituality. If tracing on historical aspects, Sufism plays a role in guarding and guiding human life's journey so that the world and the hereafter are safe (Nata, 2012). This position emphasizes how Sufism is needed in preaching, both as a da'wah method and Islamic teachings. This is deemed necessary to remember, the problems in the millennial are also quite complicated.

The problems faced by the millennials have a different style when compared to the previous generation. While carrying out the mandatory religious ritual processes, for example those listed in the Rukun Islam and Muamalah. The essence for Muslims is that they must have provisions regarding Sufism's values contained therein (Ibda, 2018) . On the other hand, it must be admitted that millennials have now become specific targets for modernization and the development of modern civilization (Nuraini \& Marhayati, 2019). This awareness also needs to be understood by preachers, if sufism is an integral part of guarding the all-digital millennial life. 


\section{Growing Millenial Spirituality}

The life of the millennial generation which is increasingly complex sometimes keeps them away from religious activities. Because one of the characteristics of millennials is freedom (Nata, 2018). They often experience spiritual emptiness. Sufistic preaching is needed to cultivate the spiritual soul of the millennial generation. One thing that is carried out in sufistic preaching is related to morality. Although morality requires parents' direct education, it often experiences various obstacles, especially when dealing with information technology, such as mobile phones (Khamim, 2019).

This fact needs to be embraced by preachers through sufistic preaching that Islamic ethics can be practiced. Islamic ethics is a science that can understand the boundaries of good and evil or between those who are praiseworthy and despicable, both in words and deeds both physically and mentally (Widyastini, 2000) One of the da'wah that can accommodate this is Sufistic da'wah. Because Sufism is an Islamic teaching that explains how a Muslim's moral attitude should be in having a good relationship with God (vertical) and having good relations with fellow humans (horizontal) (Mustadi, 2015). Millennials needs a new paradigm in carrying out Islamic preaching (Ghofur, 2019).

Building the spirituality of millennials is very much needed in today's modern life. The emergence of the spirituality movement is a form of reaction to the modern world that emphasizes profane material things (Ulfah, 2017). Sufistic preaching is appropriate if carried out today during a modern life and increasingly undermining human life, especially the millennial generation. It is not without reason, because one of the emphasized tasawwuf teachings is the wara' attitude. In the Sufi world, Wara' refers to a life pattern and life by always being vigilant in doing (Tangngareng, 2017). Sufistic preaching will lead to the morality of human life and foster an excellent spiritual and religious spirit. Because in tasawuf there must be an increase in morality, that is, anyone who practices Sufism affects Akhlaqul Karimah (Gitosaroso, 2015).

\section{Forming Moderate Milenial Muslims}

One of the opportunities for multicultural preaching to the millennial is to build moderate Muslims. Moderate Islamic practice can refer to what was taught by the Prophet Muhammad, his companions and followed by Nine Saints or Walisongo 
(Miftahuddin, 2010). Moderate Islamic practices can be carried out and given to millennials through multicultural preaching carried out by preachers. This is in line with the millennial social emptiness which then raises the spirit of emigrating. While the development of millennial Islamic hijrah in Indonesia is extensive, one of which is due to individuals' or groups' desire to become better individuals from the Islamic side (Fajriani, 2019).

One of the multicultural da'wah missions is to form a moderate Muslim person or wasatiyyah (Salik, 2019). A moderate attitude or wasatan people are not frozen towards what they know, and vice versa, who are also not closed or closed to knowledge and have good health in their feelings and thoughts (Nugroho \& Hidayat, 2019). The choice to become a moderate Muslim needs to be nurtured from an early age, especially for the millennial. They are not trapped in a rigid and textual understanding of religion (Fransisca, 2019). A moderate attitude in religion is essential to embrace the diversity that exists, whether group, race, ethnicity, or culture in Indonesia which will undoubtedly cause differences in these groups (Afif \& Dwijayanto, 2021).

The choice of multicultural da'wah is also a bulwark of the harsh tendency of preaching, mostly targeting millennials, particularly when recently phenomena of antiwestern, anti-non-Muslim and even anti-democracy (Nugraha et al., 2020). For moderate Muslims, this phenomenon is considered dangerous for the life of the nation and state in Indonesia (Puadi, 2014). This has resulted in radicalism caused by faulty religious understanding which is always an interesting issue. One of the crucial moments for the awakening of Islam in Indonesia at the end of the New Order era was a precondition for the emergence of various Islamic movement groups including the radical Islamic movement (Prasetiawati, 2017). Multicultural da'wah is the direction of understanding Islam how Muslims are religious in the right way. The emphasis is on the understanding that Islamic law has a flexible character according to developmental conditions and the needs of the times (Amin, 2014). This understanding must be understood by millennials who tend to be thirsty for religion and knowledge of Islamic religious law not to be trapped in a rigid understanding. Moreover, moderation in Islam has evident roots, which are sourced from the Islamic sources of the Qur'an and the Sunnah of the Prophet (Al-Rasyid, 2014). 


\section{Towards the "Insan Ulul Albab"}

Two concepts between multicultural-Sufism are terms that have interrelated meanings. Both of them will lead humans to become Ulul Albab beings. Insan Ulul Albab is a human group; without being guided, Ulul Albab will move them to guide people towards a better life (Qodratulloh, 2016). It follows the objectives of multiculturalsufistic preaching so that honey, especially millennials, can continue to grow into humans who are advancing in a better direction. Millennials who are on average able to get higher education must always guide to contextualize the teachings and policies of the Prophet Muhammad with a tolerant, peaceful, democratic, humanist, and multicultural life (Fatoni, 2015).

Multicultural-Sufism in da'wah has a significant role in realizing Ulul Albab people. The Ulul Albab is a person who has an advantage in the form of aqal or thought and qalb can use it (Hunsouw, 2013). Millennials who have this open attitude will undoubtedly accept the various things that come in very quickly because Ulul Albab is a human being who is capable and has the characteristics of individual shifting, social shifting, spiritual depth, and emotional sensitivity (Yaqin, 2015). It shows how the Ulul Albab concept is the ideal of every human being on this earth, including the millennial. So they hope to achieve Ulul Albab through four keywords that are the essence of the Ulul Albab profile according to the Qur'an, such as zikr, tazakkur, tafakkur and taqwa (Herawati, 2015).

\section{Conclusion}

The millennial era is full of information and technology. Millennials are born from a communication and information exposure that has been born due to the growth of various developing communication technologies. Preachers must more develop the current preaching through a more intimate approach to their spiritual aspects. The aim is none other than that their spirituality covered by the glitter of developing technology can grow properly. So it requires a more fundamental religiosity approach. One of the offers is through sufistic preaching and a multicultural approach.

Sufistic da'wah is needed to foster the millennial's spirit, which currently seems to immerse due to their changing new culture. The Sufistic approach in preaching functions in two ways: a peaceful da'wah approach and da'wah's message. While on 
another aspect, the millennial has grown in extraordinary diversity. The inculcation of pluralism values is also essential in da'wah. The millennial has lived beyond the sociocultural boundaries that have grown along with their interactions.

The roles of both of them are essential to prioritize in current preaching. The cultural diversity and the fading of human spirituality are a necessity. Da'wah needs to take a strategic role and have a strategic position in fostering human life, which in this aspect is indeed the reality of da'wah, which continues to occur along with the spirit of Muslims in conveying messages of God.

\section{References}

Afandi, M. (2018). Potret Masyarakat Multikultural di Indonesia. Multicultural of Islamic Education, 2(1), 1-10. http://yudharta.ac.id/jurnal/index.php/ims

Afif, Y.U., \& Dwijayanto, A. (2021), Moderate Islamic Education and Religious Digital Literature: The Making of Children's Moderate Identities Through the NU Kids Application. Proceeding of ICIS: International Conference on Islamic Studies, 2(1), 1-9. http://dx.doi.org/10.4108/eai.27-10-2020.2304174

Akhsania, K. N. (2018). Pendidikan Karakter Prososial di Era Milenial dengan Pendekatan Konseling Realitas. Prosiding SNBK, 2(1), 228-233. http://prosiding.unipma.ac.id/index.php/SNBK/article/view/494

Akmaliah, W. (2020). The demise of moderate Islam: new media, contestation, and reclaiming religious authorities. Indonesian Journal of Islam and Muslim Societies, 10(1), 1-24. doi:https://doi.org/10.18326/ijims.v10i1.1-24

Al-Rasyid, H. H. (2014). DAKWAH ISLAM DI ERA GLOBALISASI: REVITALISASI PRINSIP $\begin{array}{llll}\text { MODERASI ISLAM. } & \text { Al-Qalam, }\end{array}$ https://doi.org/http://dx.doi.org/10.31969/alq.v20i3.337

Amin, R. M. (2014). PRINSIP DAN FENOMENA MODERASI ISLAM DALAM $\begin{array}{llll}\text { TRADISIHUKUM ISLAM. } & \text { 20(3), }\end{array}$ https://doi.org/http://dx.doi.org/10.31969/alq.v20i3.339

Aminudin. (2016). Konsep Dasar Dakwah. Al-Munzir, 9(1), 29-46.

Anwar, S., \& Salim, A. (2019). Pendidikan Islam dalam Membangun Karakter Bangsa di Era Milenial. Al-Tadzkiyyah: Jurnal Pendidikan Islam, 9(2), 233. https://doi.org/10.24042/atjpi.v9i2.3628

Aripudin, A \& Abdullah, M. (2014). Perbandingan Dakwah, Bandung: Remaja Rosdakarya.

Aripudin, A. (2016). Sosiologi Dakwah, Bandung: Remaja Rosdakarya.

Aqib, Kharisudin. (1999). "Teosofi Tarekat Qodariyah Wa Naqsabandiyah". Jurnal IAIN Sunan Ampel, Edisi XVII, Oktober-Desember.

Aziz, M. A. (2009). Ilmu Dakwah. Jakarta: Kencana.

Aziz, S. (2017). Pendidikan Spiritual Berbasis Sufistik Bagi Anak Usia Dini Dalam Keluarga. Jurnal Dialogia, 15(1), 131-150.

Azmar, S. (2001). Metode Penelitian, Yogyakarta: Pustaka Pelajar 
Azra, Azyumardi. (1998). Jaringan Ulama Timur Tengah dan Kepulauan Nusantara Abad XVII-XVIII, Bandung: Mizan.

Azra, Azyumardi, dkk. (2015). Fikih Kebinekaan. Bandung: Mizan.

Bachtiar, Wardi. (1997). Metodologi Penelitian Ilmu Dakwah, Jakarta: Logos

Bisri, A. (2014). Islam Rahmatan Lil-' Alamin Sebagai Landasan Dakwah Multikuktural: Perspektif Muhammad Fethullah Gülen. Jurnal Walisongo, 22(2), 479-494.

Bungin, Burhan. (2007). Penelitian Kualitatif, Komunikasi, Ekonomi, Kebijakan Publik, dan Ilmu Sosial lainnya, Jakarta: Kencana Prenada Media Grup.

Bruinessen, Martin Van. (2012). Kitab Kuning, Pesantren dan Tarekat, edisi revisi, Yogyakarta: Gading Publishing.

Cholil, U. (2018). Belajar Tarekat di Perguruan Tinggi. Jurnal Terateks, 3(1), 1-15.

Djamaluddin. (2008). Reorientasi Pembelajaran Akhlak Tasawuf Di Perguruan Tinggi. Tadris, 3(1), 1-13.

Elmansyah, E. (2016). Dakwah Sufistik Di Era Digital. Al-Hikmah, 10(1), 56-74. https://doi.org/10.24260/al-hikmah.v10i1.547

Fahrimal, Y. (2018). Netiquette: Etika Jejaring Sosial Generasi Milenial Dalam Media Sosial. Penelitian Pers Dan Komunikasi Pembangunan, 22(1), 69-78.

Fajriani, S. W. (2019). Hijrah Islami Milenial Berdasarkan Paradigma Berorientasi Identitas. Sosioglobal: Jurnal Pemikiran Dan Penelitian Sosiologi, 3(2), 76. https://doi.org/10.24198/isg.v3i2.21643

Fatoni, A. (2015). Perguruan Tinggi Islam Dalam Mencetak Generasi Ulul Albab. AlTadzkiyyah: Jurnal Pendidikan Islam, 6(1), 134-146.

Fransisca, M. (2019). Moderat Antar Umat, Organisasi dan Pendidikan. JUSPI Jurnal Sejarah Peradaban Islam), 3(1), 85. https://doi.org/10.30829/juspi.v3i1.4375

Gitosaroso, M. (2015). Tasawuf Dan Modernitas (Mengikis Kesalahpahaman Masyarakat Awam Terhadap Tasawuf). Al-Hikmah, 10(1). https://doi.org/10.24260/alhikmah.v10i1.550

Ghofur, A. (2019). Dakwah Islam Di Era Milenial. Dakwatuna: Jurnal Dakwah Dan Komunikasi Islam, 4(1), 25. https://doi.org/10.22515/balagh.v4i1.1557

Habibi, M. (2018). Optimalisasi Dakwah Melalui Media Sosial Pada Era Milenial. AlHikmah, 12(1), 101-116. https://doi.org/10.24260/al-hikmah.v12i1.1085

Hamzah, A. R. (2018). Pendidikan Spiritual Dalam Kitab Tuhfah Al-Maudud Bi Ahkami Al-Maulud Karya Ibnu Qoyyim Al-Jauziyyah. Tarbawiyah: Jurnal Ilmiah Pendidikan, 02(1), 1-27.

Haq, T. Z. (2020). Pola Asuh Orang Tua Dalam Perilaku Sosial Generasi Millenial Ditinjau Dari Neurosains. Al-Mada: Jurnal Agama, Sosial, Dan Budaya, 3(1), 88-108. https://doi.org/10.31538/almada.v3i1.609

Haryanto, J. T. (2014). Perkembangan Dakwah Sufistik Perpektif Tasawuf Kontemporer. Addin, 8(2), 269-294.

Herawati, A. (2015). Kontekstualisasi Konsep Ulul Albab Di Era Sekarang. Jurnal Fikrah, $3(1), 123-140$.

Hidayatullah, S., Waris, A., \& Devianti, R. C. (2018). Perilaku Generasi Milenial dalam Menggunakan Aplikasi Go-Food. Jurnal Manajemen Dan Kewirausahaan, 6(2), 240249. https://doi.org/10.26905/jmdk.v6i2.2560

Huda, Sokhi. (2018). Spirit Moral Dalam Dakwah Sufistik Gerakan Hizmet M. Fethullah Gulen, Surabaya: Paper UIN Sunan Ampel Surabaya.

Huda, Z. (2016). DAKWAH ISLAM MULTIKULTURAL (Metode Dakwah Nabi SAW Kepada Umat Agama Lain). Religia, 19(1), 89. https://doi.org/10.28918/religia.v19i1.661 
Fatoni, A. (2015). Perguruan Tinggi Islam Dalam Mencetak Generasi Ulul Albab. AlTadzkiyyah: Jurnal Pendidikan Islam, 6(1), 134-146.

Ibda, H. (2018). Penguatan Nilai-Nilai Sufisme Dalam Nyadran Sebagai Khazanah Islam $\begin{array}{lllll}\text { Nusantara. Jurnal Islam } & 148 .\end{array}$ https://doi.org/10.33852/jurnalin.v2i2.92

Ana Irhandayaningsih. (2018). Kajian Filosofis Terhadap Multikulturalisme Indonesia. Jurnal Oasis, Vol 15, No, 1-20.

Ismail, A. I. dan Hotman P. (2011). Filsafat Dakwah: Rekayasa Membangun Agama dan Peradaban Islam, Jakarta: Kencana.

Jannah, N. (2019). Strategi Komunikasi Dakwah Wilayatul Hisbah dalam Pencegahan Pelanggaran Qanun Aceh tentang Jinayat di Aceh Barat. Jurnal Ilmu Dakwah, 39(2), 183-196. https://doi.org/http://dx.doi.org/10.21580/jid.v39.2.4401

Khamim, N. (2019). Penerapan Pendidikan Agama Islam pada Keluarga Millenial. Attaqwa: Jurnal Ilmu Pendidikan Islam, 15(2), 1689-1699. https://doi.org/10.1017/CB09781107415324.004

Kymlicka, Will. (2000). Multicultural Citizenship, A Liberal Theory of Minority Rights, New York: Oxford University Press

Lalo, K. (2018). Menciptakan Generasi Milenial Berkarakter dengan Pendidikan Karakter guna Menyongsong Era Globalisasi. Jurnal Ilmu Kepolisian, 12(2), 68-75.

Lestari, G. (2015). Bhinnekha Tunggal Ika: Khasanah Multikultural. Jurnal Pendidikan Pancasila Dan Kewarganegaraan, I(Februari), 31-37. https://doi.org/http://dx.doi.org/10.17977/jppkn.v28i1.5437

Lestariningsih, W. A., Jayusman, J., \& Purnomo, A. (2018). Penanaman Nilai-Nilai Multikultural dalam Pembelajaran Sejarah di SMA Negeri 1 Rembang Tahun Pelajaran 2017/2018. Indonesian Journal of History Education, 6(2), 123-131.

Lubis, A. Y. (2006). Dekonstruksi Epistemologi Modern, Jakarta: Pustaka Indonesia Satu.

M, A. Z., \& M. (2013). Tarekat Qodariyah Wa Naqsabandiyah Syaikhona Syaikhona Muhammad Kholil Bangkalan Tahun 1834-1925. AVATARA, e-Journal Pendidikan Sejarah, 1(2), 89-99.

Makhfud, S. A. (1970). Hidayatul Mursyidin, terj. Chodijah Nasution. Yogyakarta: Usaha Penerbitan Tiga A.

Marfu'ah, U. (2018). Strategi Komunikasi Dakwah Berbasis Multikultural. Islamic Communication Journal, 2(2), 147. https://doi.org/10.21580/icj.2017.2.2.2166

MG, N. (2019). Aktualisasi Dakwah Dai Millennial di Ruang Maya: Perspektif Etika Dakwah dengan Studi Kasus di Kota Medan. Jurnal Ilmiah Islam Futura, 18(1), 105. https://doi.org/10.22373/jiif.v18i1.3196

Miftahuddin. (2010). ISLAM MODERAT KONTEKS INDONESIA DALAM. Jurnal Mozaik, $V$ (2009), 41-54. https://doi.org/https://doi.org/10.21831/moz.v5i1.4338

Muhaya. A. (2001). Tasawuf dan Krisis, Yogyakarta: Pustaka Pelajar

Muhiddin, A. (2002). Dakwah Dalam Perspektif Al-Qur'an. Bandung: CV Pustaka Setia.

Mulyadi, A. (2018). Memaknai Praktik Tradisi Ritual Masyarakat Muslim Sumenep. Endogami: Jurnal Ilmiah Kajian Antropologi, 1(2), 124. https://doi.org/10.14710/endogami.1.2.124-135

Mundir, S. (2005). Metode Penelitian Membimbing dan Mengantar Kesuksesan Anda dalam Dunia Penelitian, Surabaya: Insane Cendekia.

Munir, M. \& Ilahi, W. (2006). Manajemen Dakwah. Jakarta: Prenada Group.

Mustadi. (2015). Membangun Moralitas Bangsa Dengan Tasawuf. Jurnal Ilmu Pendidikan Islam, 14(2). 
Mutmainnah, S. (2018). Sufisme Dalam Novel Khidir Karya Wiwid Prasetiyo Dan Relevansinya Dengan Pendidikan Karakter. Eksplorasi Bahasa, Sastra Dan Budaya Jawa Timuran Sebagai Upaya Penguatan Pendidikan Berbasis Ekologi.

Naldo \& Hardika Widi Satria. (2018). Studi Observasi terhadap Penggunaan Aplikasi LINE oleh Generasi Millenial. Jurnal Sosial Humaniora Terapan, 1, 32-40. https://doi.org/https://doi.org/10.7454/jsht.v1i1.33

Nata, A. (2012). Akhlak Tasawuf, Jakarta: Raja Grafindo Persada.

Nata, A. (2018). Pendidikan Islam Di Era Milenial. Conciencia, 18(1), 10-28. https://doi.org/10.19109/conciencia.v18i1.2436

Nawawi, N. (1970). Dakwah Dalam Masyarakat Multikultural. KOMUNIKA: Jurnal Dakwah Dan Komunikasi, 6(1). https://doi.org/10.24090/komunika.v6i1.347

Nawawi, N. (1970). Kompetensi Juru Dakwah. KOMUNIKA: Jurnal Dakwah Dan Komunikasi, 3(2), 287-297. https://doi.org/10.24090/komunika.v3i2.131

Nazir, M. (2014). Metode Penelitian, Jakarta: Ghalia Indonesia.

Natsir, M. (1989). Fiqhud Dakwah, Semarang: Roma Ahani.

Nugraha, R., Parhan, M., \& Aghnia, A. (2020). MOTIVASI HIJRAH MILENIAL MUSLIM PERKOTAAN MELALUI DAKWAH DIGITAL. MUHARRIK: Jurnal Dakwah Dan Sosial, 3(02), 175-194. https://doi.org/10.37680/muharrik.v3i02.398

Nugroho, B. T. A., \& Hidayat, W. N. (2019). Generasi Muslim Milenial Sebagai Model Islam Wasatiyyah Zaman Now. AT-TAHDZIB: JURNAL STUDI ISLAM DAN MUAMALAH, 7(1), 32-50. https://doi.org/https://doi.org/10.21831/moz.v5i1.4338

Nuraini Nuraini, N. M. (2019). NILAI-NILAI TASAWUF GENERASI MILENIAL. Jurnal Nuansa, 12(2). https://doi.org/http://dx.doi.org/10.29300/nuansa.v12i2.2759

Pardianto. (2015). DAKWAH MULTIKULTURAL Studi Alternatif Dakwah di Era Globalisasi). Jurnal Mediasi, 9(2).

Puadi, H. (2014). Muslim Moderat dalam Konteks Sosial Politik. Jurnal Pusaka, 4-13.

Purwantiningsih, A., \& Permana, S. A. (2019). DALAM PEMBELAJARAN ILMU PENGETAHUAN SOSIAL. Penguatan Muatan Lokal Bahasa Dan Sastra Daerah Sebagai Fondasi Pendidikan Karakter Generasi Milenial, 0291.

Putra, Y. S. (2016). Theoritical Review : Teori Perbedaan Generasi. Jurnal Ilmiah Among Makarti, 9(18), 123-134. http://repositorio.unan.edu.ni/2986/1/5624.pdf

Prasetiawati, E., \& Dosen. (2017). Menanamkan Islam Moderat Upaya MenanggulangiRadikalisme di Indonesia. Fikri: Jurnal Kajian Agama, Sosial Dan Budaya, 2(2). https://doi.org/https://doi.org/10.25217/jf.v2i2.152

Qodratulloh S, W. (2016). Konsep ulul albâb dalam al- Quran dan implikasinya dalam pembelajaran pendidikan agama Islam di perguruan tinggi. Jurnal Sigma-Mu, 8(1), 17-24.

Rahmatullah, R., \& Said, A. (2019). Implementasi Pendidikan Karakter Islam Di Era Milenial Pada Pondok Pesantren Mahasiswa. Journal TA'LIMUNA, 8(2), 37. https://doi.org/10.32478/talimuna.v8i2.269

Rahmatullah, A. S. (2019). Qalbun Healing Berbasis Tasawuf:Upaya Menyehatkan Jiwa Terhadap Homoseksual. Psikis: Jurnal Psikologi Islami, 5(1). https://doi.org/10.19109/Psikis.v5i1.2572

Rahmatullah, A. S., \& Azhar, M. (2019). PENDIDIKAN SPIRITUAL BERBASIS TASAWUF ( Upaya Meminimalisir Perilaku Menyimpang Homoseksual di Pesantren ). Cendekia, $17(2), 235-252$.

Rehayati, R. (2012). Filsafat Multikulturalisme John Rawls. Jurnal Ushuluddin, XVIII(2).

Rohmiyati, Y. (2018). Model Perilaku Pencarian Informasi Generasi Milenial. Anuva, 2(4), 387. https://doi.org/10.14710/anuva.2.4.387-392 
Rosyada, D. (2014). Pendidikan Multikultural Di Indonesia Sebuah Pandangan Konsepsional. SOSIO DIDAKTIKA: Social Science Education Journal, 1(1). https://doi.org/10.15408/sd.v1i1.1200

Sabani, N. (2018). Generasi Millenial Dan Absurditas Debat Kusir Virtual. Informasi, 48(1), 95. https://doi.org/10.21831/informasi.v48i1.18078

Salik, M. (2019). CONSERVING MODERATE ISLAM IN INDONESIA: An Analysis of Muwafiq's Speech on Online Media. JOURNAL OF INDONESIAN ISLAM, 13(2), 373394. doi:http://dx.doi.org/10.15642/JIIS.2019.13.2.373-394

Salmadanis. (2000). Dakwah Dalam Perspektif Al-Qur'an dan Hadis, Jakarta: TMF

Setyawan, A. (2020). Dakwah yang Menyelamatkan: Memaknai Ulang Hakikat dan Tujuan Da'wah Islamiyah. Al-Adabiya: Jurnal Kebudayaan Dan Keagamaan, 15(02), 189-199. https://doi.org/10.37680/adabiya.v15i02.487

Siroj, S. A. (2014). Islam Sumber Budaya Inspirasi Budaya Nusantara: Menuju Masyarakat Mutamaddin, Jakarta: LTNU.

Suhandang, K. (2014). Strategi Dakwah: Penerapan Strategi Komunikasi dalam Dakwah, Bandung: PT Remaja Rosdakarya.

Sulistyawati, D., \& Santosa, I. (2019). PENGARUH PERILAKU BUDAYA GENERASI MILLENIIAL MENGHADAPI REVOLUSI INDUSTRI TERHADAP RUANG HUNIAN PRIBADI DENGAN STUDI KASUS ' ONE ROOM LIVING' MAHASISWA. Jurnal Desain Indonesia, 1(1).

Shihab, M. Q. (2002). Tafsir Al-Misbah Vol. 6. Jakarta: Lentera Hati.

Syafriani, D. (2017). Hukum Dakwah Dalam Al-Qur'an Dan Hadis. FUADUNA: Jurnal Kajian Keagamaan Dan Kemasyarakatan, 1(1). https://doi.org/http://dx.doi.org/10.30983/fuaduna.v1i1.439

Syuhud. (2014). IMPLEMENTASI PENDIDIKAN SPIRITUAL QOUTIENT (Studi MTs Miftahul Huda Selok Anyar Pasirian). Jurnal Tarbiyatuna, 7(2), 1-17.

Tangngareng, T. (2017). Puncak-Puncak Capaian Sufistik Dalam Perspektif Metodologis. Aqidah-Ta: Jurnal Ilmu Aqidah, 3(1), 83-97. https://doi.org/10.24252/aqidahta.v3i1.3410

Takdir, M. (2016). Kontribusi Kiai Kholil Bangkalan dalam Mengembangkan Tasawuf Nusantara. 'Anil Islam: Jurnal Kebudayaan Dan Ilmu Keislaman, 9(2), 268-299. http://jurnal.instika.ac.id/index.php/AnilIslam/article/view/18

Tajuddin, Y. (2014). Walisongo dalam Strategi Komunikasi Dakwah. Jurnal ADDIN, 8(2), 367-390. https://doi.org/http://dx.doi.org/10.21043/addin.v8i2.602

Tilaar, H. A. R. (2014). Multikulturalisme, Bahasa Indonesia, Dan Nasionalisme Dalam Sistem Pendidikan Nasional. Jurnal Dialektika, 1(2), 213-224. https://doi.org/10.15408/dialektika.v1i2.6287

Ulfah, N. M. (2017). Tasawuf Modern Studi Pemikiran Hamka (Haji Abdul Malik Karim Amrullah). Esoterik, 2(1), 95-109. https://doi.org/10.21043/esoterik.v2i1.1896

Wahana, H. D. (2015). PENGARUH NILAI-NILAI BUDAYA GENERASI MILLENNIAL DAN BUDAYA SEKOLAH TERHADAP KETAHANAN INDIVIDU (Studi Di SMA Negeri 39, Cijantung, Jakarta). Jurnal Ketahanan Nasional, 21(1), 14. https://doi.org/10.22146/jkn.6890

Wahono, M. (2018). Pendidikan Karakter: Suatu Kebutuhan Bagi Mahasiswa Di Era $\begin{array}{llll}\text { Milenial. Jurnal Integralistik, 29(2), } & \text { 1-7. }\end{array}$ https://doi.org/10.15294/integralistik.v29i2.16696

Wahyunanto, E. . D., Dwijayanto, A., \& Wathoni, S. (2021). GUS DUR DAN CIVIL SOCIETY: PERAN KH ABDURRAHMAN WAHID DALAM PEMBERDAYAAN 
MASYARAKAT. AICOMS: Annual Interdisciplinary Conference on Muslim Societies, 1, $1-20$. Retrieved from https://prosiding.insuriponorogo.ac.id/index.php/aicoms/article/view/1

Walidah, I. Al. (2018). Tabayyun di Era Generasi Millenial. Jurnal Living Hadis, 2(2), 317. https://doi.org/10.14421/livinghadis.2017.1359

W, R. W. A., Poluakan, M. V., Dikayuana, D., Wibowo, H., \& Raharjo, S. T. (2020). Potret Generasi Milenial Pada Era Revolusi Industri 4.0. Focus : Jurnal Pekerjaan Sosial, 2(2), 187. https://doi.org/10.24198/focus.v2i2.26241

Widyastini. (2000). Nilai-nilai Moral yang Terkandung dalam Tasawuf Al-Ghazali dan Pengaruhnya terhadap Etika Islam. Jurnal Filsafat, 31(2), 208-217. https://doi.org/10.22146/if.31346

Yaqin, A. (2015). Ulul Albab Sebagai Potret Manusia Ideal (Studi Semantik al-Qur'an) 9. Jurnal Okara, 1(1), 18-34.

Zaprulkhan, Z. (2017). Dakwah Multikultural. Mawa'Izh: Jurnal Dakwah Dan Pengembangan Sosial Kemanusiaan, 8(1), 160-177. https://doi.org/10.32923/maw.v8i1.703

Zed, M. (2003). Metode Penelitian Kepustakaan. Jakarta: Yayasan Obor Indonesia.

Zhafira, T. (2018). Sikap asosial pada remaja era millenial. Sosietas, 8(2), 501-504. https://doi.org/https://doi.org/10.17509/sosietas.v8i2.14591 